Acta Regionalia et Environmentalica 2

Nitra, Slovaca Universitas Agriculturae Nitriae, 2019, pp. 45-52

\title{
FINANCIAL AND PERSONAL ISSUES OF THE TRANSFERRED STATE ADMINISTRATION COMPETENCIES IN THE BUILDING PROCEDURE TO MUNICIPALITY OFFICES
}

\author{
Ivana LICHNEROVÁ \\ Slovak University of Agriculture in Nitra, Slovak Republic
}

\begin{abstract}
The aim of the paper is to draw attention to consequences of the transfer of competency at the level of the building procedure from state authorities to municipal offices in the Slovak Republic and the Czech Republic. The defined research objective was achieved firstly by conducting controlled interviews with representatives of the building offices in the Nitra Region and, secondly, by analysis of financing of this competency from the obtained data from publicly available sources in both states. Secondly, the paper includes a comparison of the financial management of the transferred competencies at the level of the building procedure between the Nitra Region (Slovakia) and the Pardubice Region (Czech Republic). By conducting controlled interviews in the Nitra Region, we came to the conclusion of the financial under-dimensioning of this competency. By comparing the amount of state subsidies provided for the building procedure in both regions, significant differences were found. Based on our research findings, we recommend reassessing the state subsidies for the transferred competency in the field of building procedure.
\end{abstract}

Keywords: transferred competency, building procedure, financial issues, personnel management

In the Slovak Republic, the local self-government structure is currently very fragmented, with a large number of small municipalities $(2,927)$ (Báčik, 2019). "The average municipality population size in Slovakia is only 1,870 inhabitants" (Nemec, 2018). However, each municipality, small or large, has the same original and transferred competencies for which public resources are allocated. However, the amount of these resources is insufficient for municipalities. This creates the problem which needs to be solved. For objective reasons, for a small municipality it is not possible to provide the same services and needs for citizens as a large municipality. This claim is also supported by Matejová et al. (2017), adding that the existence of too small municipalities can lead to inefficient provision of public services.

Delegation of competencies from a higher level (state) to a local level (municipalities) brings many benefits; however, the scope and the way of performance of transferred competencies remain questioned (Fuka et al., 2016).

The performance of competency in the building procedure is one of the competencies which were transferred in Slovakia to the municipalities from the state administration bodies by the Act No. 416/2001 Coll. as amended.

The National Audit Office (NAO) of the Slovak Republic in its evaluation report for 2011-2013, published the result of the effectiveness and efficiency control in the managing of powers by the municipalities of the SR in the building procedure. Its conclusion was the affirmation that 58 per cent of municipalities had to contribute from their own resources to cover the transferred competency (NAO SR, 2014),

In the Czech Republic, the powers of state administration were transferred to municipalities by the Act No. 313/2002 Coll. as amended and at the same time, municipality powers were divided by the Act No. 314/2002 Coll. as amended among municipalities with delegated municipal powers and municipalities with extended powers (Černěnko, 2017). These municipalities receive state subsidies from the budget of the Czech Republic for transferred competencies at the level of the building procedure calculated on the basis of the size of the administrative units (MICZ, 2019).

In Slovakia, funding of this transferred competency regulated by the Act No. 50/1976 Coll. - building law, is financially costly. The law precisely determines the level of education of building office employees, whereby they are obliged to have a university degree and 3 years of professional experience in the field or secondary education and 5 years of the professional experience.

Concerning the financing of the transferred competency within the stipulations of the Decree of the Ministry of Transportation, Construction and Regional Development of the Slovak Republic from December 21, 2010, No 20786/2010-SRVS/Z.5414-M, the state is obliged to contribute the sum of $1.11 €$ per inhabitant for the performance of transferred state administration at the level of the building procedure to each municipality (all municipalities are "Building Authorities" within the Section

Contact address: Ing. Ivana Lichnerová, Slovak University of Agruculture in Nitra, Faculty of European Studies and Regional Development, Department of Law, 94976 Nitra; e-mail: xlichnerovai@is.uniag.sk 
117 of the Act No. 50/1976 Coll. - building act as amended. However, as for the effective financial and personnel provision, subsidy of the transferred performance of state administration at the level of the building procedure to municipalities, is used in accordance with the law - Act No. 369/1990 Coll. as amended:

The Act No.369/1990Coll.on the municipalestablishment states that municipalities can cooperate with each other on the basis of a contract, and mutual advantages, provided by the Section 20 of the Act.

Klimovský et al. (2014) consider cooperation between municipalities as the key tool to overcome the shortcomings associated with the fragmentation of municipalities. Bryson (2008) comments it also positively.

In the first part of this paper we explain consequences of that part of the reform of public administration in Slovakia (2000-2004) when more than 300 competencies (Marišová et al., 2016) from the state government were transferred to local self-government institutions. It was wide-scale decentralization (Buček, 2017). In this part of the paper, we also mention the transferred competencies from the state to municipalities in the Czech Republic. In the second part of the paper we describe samples of primary data concerning the current situation of voluntary cooperation among municipalities in the building procedure in the SR and in the Nitra Region (NR). In the third part we describe the state subsidy and personal management of the competencies in the building procedure in the SR and in the NR Region. In this section we also express the difference of the amount of the subsidy for the building procedure between the Nitra Region (SR) and the Pardubice Region (CZ). The paper also includes the opinions of employees of the building authorities in the NR Region. In the conclusion, we recommend to change the state subsidy policy in the Slovak Republic in favour of the competency in the building procedure sector.

\section{Material and methods}

The aim of the paper is to analyse the consequences of the decentralizastion process of public administration of the Slovak Repubic due to which a large number of state competencies were transferred to municipalities. We deal with the competency at the level of the building procedure - its financial and personnel provision. On the one hand, the paper contains information about the financing of competencies at the level of the building procedure in the SR and the requirements for the qualification skills of employees of building authorities. The paper also includes a comparison of the financial management of the transferred competencies at the level of the building acts between Nitra (SR) and Pardubice (CZ) Regions.

The paper is supplemented by data on the number (26) of joint building offices (JBO) and non-joint (11) building offices (NBO) performing competencies at the level of the building procedure separately in the SR and in the NR Region and about their financial issues. At the same time, the paper is supplemented by the data on municipalities (42) with delegated municipal powers and municipalities with extended powers in the building procedure sector in the Pardubice Region (CZ).
By means of qualitative research carried out in the municipalities of the NR Region, according to the Section 20 of Act No. 369/1990 Coll. as amended - on the municipal establishment, we came to the following conclusion: In the form of a contract at the level of the building procedure, municipalities created JBO (26) and the rest of them perform this competency independently - NBO (11).

We base our findings on the opinions of delegated employees of the building offices in the Nitra Region, on the financial and personnel management of this transferred competency. Primary information is obtained through controlled interviews with senior staff personnel of the building offices of the NR Region in the period from September 2018 to February 2019, supported by the opinions of authors dealing with identical issues. Among the identifiable quantitative data (obtained from publicly available sources) in the paper at the level of the NR Region, there are: the number of JBO, the number of NBO (source: Ministry of Interior of the Slovak Republic), the number of inhabitants living in municipalities with individual joint building offices (JBO) and non-joint building offices (NBO), (based on data from the Statistical Office of the SR), the number of operations of building offices and the amount of subsidies for the transferred competency of the building procedure for individual JBO and NBO in the NR Region.

The primary data for the Pardubice Region include the number of inhabitants living in the Pardubice Region, number of municipalities with delegated municipal powers and municipalities with extended powers falling under the building offices on the territory of the Pardubice Region (42) and the amount of the state subsidy for building procedure for building offices in the Pardubice Region (Pardubice Region, 2011).

The annual amount of the subsidies for the transferred state administration performance in Slovakia was expressed at the level of the building procedure for joint building offices and non-joint building offices by the following formula:

state subsidies $=$ population as on December $31 \times 1.11 €$

$1.11 €$ - inhabitant "Decree of Ministry of Transport, Construction and Regional Development of the Slovak Republic N. 20786/2010-SRVS/z.54145-M“

The amount of the total state subsidy for one act of operation of the building office:

$$
\text { subsidies for operation }=\frac{\text { total state subsidy for a building office }}{\begin{array}{c}
\text { number of operations of a building } \\
\text { office/year }
\end{array}}
$$

\section{Results and discussion}

During the Public Administration reform in 2000-2004, the Government of the Slovak Republic approved "The Conception of Decentralization and Modernization of Public Administration", by which more than 300 competencies were transferred from local state government (regional and district offices) to territorial self-government. This is the 
most difficult period of public administration development. The Act No. 416/2001 Coll., the so-called Small Competency Law, came to force (Marišová et al., 2016).

In the Czech Republic, similarly to Slovakia, a large number of competencies were transferred from the state government to municipalities by the Act No. 313/2002 Coll. as amended and at the same time the powers of municipalities were allocated by the Act No. 314/2002 Coll. as amended between municipalities with delegated municipal powers or municipalities with extended powers.

However, there is the following difference in the public administration reform, related to building competencies in Slovakia and the Czech Republic: In Slovakia, building competencies are performed by every municipal office, and in the Czech Republic, building offices are established in municipalities of II. and III. categories (municipalities with delegated municipal powers and municipalities with extended powers). Municipalities of the Czech Republic are divided into individual categories under the Act No. 314/2002 Coll. as amended (Černěnko, 2017).

The current problem of territorial self-government in the Slovak Republic is the lack of ability of some small municipalities to perform the competencies entrusted to them (Hvišč, 2017).

The requirement to solve this problem lies mainly in its impact on the efficiency and quality of the competencies carried out by self-governments as well as the financial under-dimensioning of the transferred competency.

According to the Section 20 of the Act No. 369/1990 Coll. on municipality establishment as amended, municipalities have the option, on a voluntary basis, to perform certain competencies within a contract of cooperation. Since 2002, 189 joint building offices (JBO) have been established, which covers 2,460 municipalites. The rest of Slovak municipalities (278) perform their competencies on their own (non-joint building offices) (Ministry of Interior of the SR, 2018). It is and example of joint building offices, operating on the basis of cooperation of municipalities within the understanding of the Section 20 of the Act No. 369/1990 Coll. on municipal establishment (Hrabánková et al., 2010).

The total number of municipalities in the Czech Republic is 6,257 . The competency in the building procedure is implemented by 388 municipalities of II. category (municipalities with delegated municipal powers) and 205 municipalities of III. category (municipalities with extended powers) (MICZ, 2019). As for the Pardubice Region, there are in total municipalities (451), out of them 15 municipalies of II. category and 26 municipalies of III. category (Towns and Communities Online Portal, 2019).

The NR Region is specific, as 343 municipal offices belong to $26 \mathrm{JBO}$ and only 11 perform the competency of building procedure individually - NBO (MISR, 2018). Thus, 96.89 per cent of the Nitra Region municipalities are part of joint building offices.

For the aim of the VEGA project, No. 1/0190/17, "Analysis of models of public services delivery in the field of construction order performance from the aspect of technical, size, and spatial allocation efficiency of local governments" and for the elaboration of the dissertation under the title:" Assessment of the competencies of municipal performance in the construction order sector", data on the amount of acts of individual offices were obtained from individual JBO and NBO of the NR region and within the frame of qualitative evaluation. Controlled interviews were conducted with staff members of joint building office (JBO) and non-joint building office (NBO): As many as 24 joint building offices (JBO) out of the $26 \mathrm{JBO}$ and 9 building offices (NBO) out of the 11, which perform the competency at the level of the building procedure separately (NBO) in the NR Region, participated in the controlled interview.

Among the main reasons for merging offices in the sphere of building according to controlled interviews with staff members of building authorities in the NR, there were the following factors: size of municipalities, localization of municipalities, qualified personnel, and technical and material conditions of the authorities.

These are the factors that effectively influence the transferred competency performance at the level of the building regulations. Narbón Perpiña and DeWitte (2018) discuss them similarly in their study, complementing them by: population, complete infrastructure build-up, providing of public services, etc.

The JBO in the Nitra Region were asked the following questions:

1. Has your JBO been bound to recruit another employee to provide the acts of the building procedure?

2. Legislative regulation requiring law education of employees of the building offices, which was the subject of a draft amendment to the Act No. 50/1976 Coll. - Building Act, as amended, is still absent. Is law education of employees necessary?

3. Would you suggest the change of fixed rate of state subsidies?

The first question was answered by all 24 JBOs. Nine of them said "yes", that is, they had to recruit a new employee to perform acts of JBOs, and it was found that the main reason was the annual increase in the building office's agenda and the demands of the state. However, this increase in the number of employees could only be realized after the approval by mayors of the municipalities that fall under the individual JBOs. At the same time, the offices should commit to finance jointly the monthly wages from their own resources because the state subsidy on transferred competency is insufficient.

Fifteen authorized employees of JBOs in the NR Region, who answered the identical question, replied that the number of employees of JBOs has not increased. However, the increase in the number of employees has not been realized, not because they would not need another employee, but because of financial incapability of JBOs to pay them. The employees, during the controlled interview, also pointed out to the the fact that young people who would have the qualification to fill a job at building office, are not interested in such a work because of financial under-dimensioning.

The Section 2a of the Act No. 50/1976 Coll. - the Building Act, as amended, stipulates that an employee of a building office can be a professionally qualified natural person who is irreproachable, has a higher eduation degree or a bachelor degree in the relevant field and at least three years of 
experience in the relevant field. Other possibility for an employee is to have :

- secondary education in the relevant field completed by a final exam,

- five years of experience in the relevant field,

- qualifying examination.

"Legislative regulation requiring law education of employees of building offices which was the subject of the draft amendment to the Act No. 50/1976 Coll. - Building Act, as amended, is still absent. Is law education of employees necessary?"

This 2nd question of the controlled interview was answered: Out of the nine, eight (NBO: Dvory nad Žitavou, Hájske, Ivanka pri Nitre, Klížska Nemá, Komoča, Močenok, Šal'a, Vel'ké Kosihy) answered the question, three of them said "yes", but the empolyee of an NBO in Komoča pointed out that to get a person with law education to the aforementioned position on the basis of the current inadequate financial motivation is very difficult. But the motivation of employees is very important.

Nowadays, Šafránková and Šikýř (2019) say that motivation is very important to staff. A motivated and satisfied employee is the basis for the aim of a public organization.

The employees jointly agreed that an employee of a building office should be skilled in legislation and should have knowledge of technical or construction direction; it is good to have a lawyer available at a municipal office.

The employees of the JBOs and NBOs were also asked about the financing of the transferred competency in the field of the building procedure.

According to the Act No. 523/2004 Coll. on budgetary rules of public administration and on amendments and supplements to some acts as amended, in accordance with the act on the state budget for a relevant financial year, municipalities and higher regional units get state subsidies for performance of transferred state administration.

In the section of the building procedure, it is about the amount of the subsidy determined in the frame of the Section 3 of the Decree of the Ministry of Transportation, Construction and Regional Development of the Slovak Republic No. 20786/2010-SRVS/ z.54145-M, which was 0.930
$€$ per inhabitant. By the decree of the Ministry of Transport, Construction and Regional Development of the Slovak Republic dated March 16, 2018, the amount of this subsidy, in terms of the same decree, was replaced by the amount of $1.11 €$ per inhabitant.

The following table 1 shows the amount of the subsidy for the transferred competency of the state administration assigned to individual building offices in 2016 by regions.

The $3^{\text {rd }}$ question of the controlled interview: "Would you suggest changing a fixed rate?" was answered by stuff members of building authorities of $24 \mathrm{JBO}$ s and 9 NBOs. The answer was yes from all $24 \mathrm{JBOs}$ and 7 NBOs. One employee of an NBO (Dvory nad Žitavou) said that he would not propose a change in the fixed rate and one employee said that he had not noticed a fixed rate yet.

The table 2 shows the following data: number of inhabitants falling under individual building offices as on December 31,2015 - JBO/NBO NR region (column 3), number of building offices activities of the Nitra Region - JBO/NBO (column 4) for 2016 (total number: building permits (BP), certificates of occupancy (CO), territorial decisions issued (TDI), additional construction permissions issued (ACPI) and other decisions issued (OD). Column 5 shows the amount of state subsidy allocated to a particular building office for 2016. The last column of the table analyzes the state subsidy in 2016 for the number of legal activities (BP, CO, TDI, ACPI, OD) recalculated state subsidy per 1 inhabitant/year. The calculation of governmental subsidies is based on the amount of subsidy for one of the above mentioned activity from the building order.

The amount of the state subsidy for the transferred state administration performance in the area of the building procedure sector for the NR for 2016 amounted to 12.59 per cent of the total state resources for this competency. The maximum volume of funds within the NR was allocated to the JBO Nitra (14.02 per cent) and subsequently to the JBO Levice (10.21 per cent) and JBO Nové Zámky (8.18 per cent). At the JBO Nitra, the most activities of employees of the building offices in the NR were registered $(1,904)$, followed by the JBO Nitrianske Hrnčiarovce $(1,230)$ and the JBO Vráble $(1,132)$. Based on the quantified amount of the state subsidy for individual building offices of the NR Region and the number of activities of employees of the building

Table 1 Subsidies for building regulations

\begin{tabular}{|l||c|c|}
\hline Region & Population as of December 31, 2015 & State subsidy for building regulations (€) \\
\hline \hline Bratislava & 625,167 & $693,935.37$ \\
\hline \multicolumn{1}{|c||}{ Trnava } & 558,677 & $620,131.47$ \\
\hline \multicolumn{1}{|l|}{ Trenčín } & 591,233 & $656,268.63$ \\
\hline Nitra & 682,228 & $757,273.08$ \\
\hline Žilina & 690,449 & $766,398.39$ \\
\hline Banská Bystrica & 655,359 & $727,448.49$ \\
\hline Prešov & 819,977 & $910,174.47$ \\
\hline Košice & 795,565 & $883,077.15$ \\
\hline Total & 5,418655 & $6,014,707.05$ \\
\hline
\end{tabular}

Source: Data-based processing by the Statistical Office of the Slovak Republic 2016 and data recalculated based on the "Decree of the Ministry of Transport, Construction and Regional Development the Slovak Republic N. 20786/2010-SRVS/Z.54145-M“" 
Table 2 Financing of competencies in Nitra Region (year 2016)

\begin{tabular}{|c|c|c|c|c|c|}
\hline $\begin{array}{l}\text { Name of JBO/NBO } \\
\text { NR Region }\end{array}$ & $\begin{array}{l}\text { Category } \\
\text { JBO/NBO }\end{array}$ & Population & $\begin{array}{l}\text { Number } \\
\text { of activities }\end{array}$ & $\begin{array}{l}\text { State subsidy for building } \\
\text { regulations (by population in } € / \text { year }\end{array}$ & $\begin{array}{c}\text { Governmental } \\
\text { Subsidies } € / \text { activity }\end{array}$ \\
\hline Andovce & NBO & 1,418 & 28 & $1,573.98$ & 56.21 \\
\hline Bátorove Kosihy & $\mathrm{JBO}$ & 9,131 & 203 & $10,135.41$ & 49.93 \\
\hline Dvory nad Žitavou & NBO & 5,131 & 67 & $5,695.41$ & 85.01 \\
\hline Hájske & NBO & 1,309 & 57 & $1,452.99$ & 25.49 \\
\hline Hurbanovo & $\mathrm{JBO}$ & 23,937 & 532 & $26,570.07$ & 49.94 \\
\hline Ivanka pri Nitre & NBO & 2,492 & 50 & $2,766.12$ & 55.32 \\
\hline Jasová & $\mathrm{JBO}$ & 2,795 & 19 & $3,102.45$ & 163.29 \\
\hline Klížska Nemá & NBO & 502 & 11 & 557.22 & 50.66 \\
\hline Kolárovo & $\mathrm{JBO}$ & 18,005 & 251 & $19,985.55$ & 79.62 \\
\hline Komárno & $\mathrm{JBO}$ & 46,668 & 683 & $51,801.48$ & 75.84 \\
\hline Komoča & NBO & 940 & 17 & $1,043.40$ & 61.38 \\
\hline Král'ová nad Váhom & $\mathrm{JBO}$ & 9,976 & 577 & $11,073.36$ & 19.19 \\
\hline Krušovce & $\mathrm{JBO}$ & 3,089 & 110 & $3,428.79$ & 31.17 \\
\hline Levice & $\mathrm{JBO}$ & 69,669 & 578 & $77,332.59$ & 133.79 \\
\hline Močenok & NBO & 4,289 & 68 & $4,760.79$ & 70.01 \\
\hline Mojmírovce & $\mathrm{JBO}$ & 5,857 & 293 & $6,501.7$ & 22.19 \\
\hline Nitra & $\mathrm{JBO}$ & 95,619 & 1,904 & $106,137.09$ & 55.74 \\
\hline $\begin{array}{l}\text { Nitrianske } \\
\text { Hrnčiarovce }\end{array}$ & $\mathrm{JBO}$ & 34,481 & 1,230 & $38,273.91$ & 31.12 \\
\hline Nové Zámky & $\mathrm{JBO}$ & 55,802 & 888 & $61,940.2$ & 69.75 \\
\hline Prašice & $\mathrm{JBO}$ & 2,350 & 73 & $2,608.50$ & 35.73 \\
\hline Solčany & $\mathrm{JBO}$ & 13,054 & 376 & $14,489.94$ & 38.54 \\
\hline Strekov & $\mathrm{JBO}$ & 2,990 & 94 & $3,318.90$ & 35.31 \\
\hline Svodín & $\mathrm{JBO}$ & 16,278 & 450 & $18,068.58$ & 40.15 \\
\hline Šahy & $\mathrm{JBO}$ & 18,230 & 211 & $20,235.30$ & 95.90 \\
\hline Šal'a & NBO & 22,714 & 627 & $25,212.54$ & 40.21 \\
\hline Štúrovo & $\mathrm{JBO}$ & 14,930 & 337 & $16,572.30$ & 49.18 \\
\hline Šurany & $\mathrm{JBO}$ & 40,915 & 705 & $45,415.65$ & 64.42 \\
\hline Tekovské Nemce & NBO & 1,079 & 19 & $1,197.69$ & 63.04 \\
\hline Tešedíkovo & $\mathrm{JBO}$ & 14,225 & 69 & $15,789.75$ & 228.84 \\
\hline Topol'čany & $\mathrm{JBO}$ & 52,854 & 1,023 & $58,667.94$ & 57.35 \\
\hline Velké Kosihy & NBO & 963 & 15 & $1,068.93$ & 71.26 \\
\hline Velký Lapáš & $\mathrm{JBO}$ & 3,658 & 215 & $4,060.38$ & 18.89 \\
\hline Vráble & $\mathrm{JBO}$ & 25,849 & 1,132 & $28,692.39$ & 25.35 \\
\hline Zemianska Olča & $\mathrm{JBO}$ & 3,755 & 56 & $4,168.05$ & 74.43 \\
\hline Zlaté Moravce & NBO & 11,787 & 354 & $13,083.57$ & 36.96 \\
\hline Želiezovce & $\mathrm{JBO}$ & 24,975 & 578 & $27,722.25$ & 47.96 \\
\hline Žitavany & $\mathrm{JBO}$ & 20,512 & 339 & $22,768.32$ & 67.16 \\
\hline TOTAL & 37 & 682,228 & 14,239 & $757,273.08$ & 53.18 \\
\hline
\end{tabular}

Source: Data-based processing by the Statistical Office of the Slovak Republic 2016 and data recalculated based on the "Decree of the Ministry of Transport, Construction and Regional Development the Slovak Republic N. 20786/2010-SRVS/z.54145-M"and data form employees of building offices 
Table 3 Financing of competencies in the Pardubice Region (year 2016)

\begin{tabular}{|c|c|c|}
\hline Municipalities with buidling office & Population & State subsidies for building regulation $(€)^{*}$ \\
\hline Tatenice & 1,284 & $8,415.65$ \\
\hline Výprachtice & 1,674 & $10,950.05$ \\
\hline Nasavrky & 1,926 & $19,708.91$ \\
\hline Sloupnice & 2,126 & $13,878.52$ \\
\hline Ronov nad Doubravou & 2,470 & $16,101.61$ \\
\hline Dolní Čermná & 2,538 & $16,540.51$ \\
\hline Dolní Dobrouč & 2,588 & $16,863.13$ \\
\hline Červená voda & 3,068 & $19,955.68$ \\
\hline Luže & 3,079 & $20,026.45$ \\
\hline Proseč u Skutče & 3,379 & $21,955.21$ \\
\hline Dašice & 3,648 & $23,682.17$ \\
\hline Seč & 3,845 & $34,694.21$ \\
\hline Bystré & 3,906 & $25,336.44$ \\
\hline Brandýs nad Orlicí & 4,106 & $16,830.87$ \\
\hline Městský úřad Slatiňany & 4,191 & $27,161.53$ \\
\hline Choltice & 4,248 & $27,526.25$ \\
\hline Březová nad Svitavou & 5,612 & $37,277.67$ \\
\hline Králíky & 5,736 & $19,936.55$ \\
\hline Chvaletice & 5,948 & $38,364.57$ \\
\hline Sezemice & 6,233 & $40,174.55$ \\
\hline Jevíčko & 6,601 & $42,508.88$ \\
\hline Skuteč & 7,407 & $47,611.11$ \\
\hline Jablonné nad Orlicí & 7,680 & $49,336.15$ \\
\hline Letohrad & 8,251 & $52,939.26$ \\
\hline Heřmanův Městec & 10,045 & $64,218.66$ \\
\hline Lázně Bohdaneč & 11,579 & $73,074.42$ \\
\hline Chrast & 12,828 & $81,604.44$ \\
\hline Žamberk & 13,231 & $46,458.54$ \\
\hline Choceň & 13,831 & $78,272.05$ \\
\hline Přelouč & 14,409 & $49,561.89$ \\
\hline Polička & 15,688 & $54,184.75$ \\
\hline Holice & 17,473 & $61,340.34$ \\
\hline Lanškroun & 17,674 & $60,739.98$ \\
\hline Vysoké Mýto & 18,166 & $61,612.23$ \\
\hline Česká Třebová & 19,332 & $64,475.05$ \\
\hline Moravská Třebová & 19,911 & $68,502.91$ \\
\hline Hlinsko & 21,222 & $73,256.88$ \\
\hline Ústí nad Orlicí & 22,048 & $74,506.83$ \\
\hline Litomyšl & 24,307 & $83,922.40$ \\
\hline Svitavy & 25,543 & $85,607.62$ \\
\hline Chrudim & 31,663 & $104,448.69$ \\
\hline Pardubice & 105,829 & $319,208.21$ \\
\hline TOTAL & 516,323 & $2,152,771.84$ \\
\hline
\end{tabular}

Source: Czech Statistical Office, 2016; Ministry of the Interior of the Czech Republic, 2016

* the amount of the state subsidy calculated by the exchange rate NBS as of March 29, 2019; $1 €=25.786$ CZK 
Table 4

Financing of competencies in Nitra and Pardubice regions

\begin{tabular}{|l||c|c|c|}
\hline Region & Municipalities & Population & State subsidies (€) \\
\hline \hline Nitra & 354 & 682,228 & $757,273.08$ \\
\hline Pardubice & 451 & 516,323 & $2,152,771.842$ \\
\hline
\end{tabular}

Source: Statistical Office of the Slovak Repubic, 2016; Ministry of the Interior of the Slovak Republic, 2018; Czech Statistical Office, 2016; Ministry of the Interior of the Czech Republic, 2016

authorities, the highest amount of funds per 1 activity was recorded at JBO Tešedíkovo (228.84 $€$ ) and subsequently at JBO Jasová (163.29 €) and JBO Levice (133.79 €). The lowest volume was found out in JBO Vel'ký Lapáš (18.89 €), JBO Králová nad Váhom (19.19€) and JBO Mojmírovce (22.19€).

It is clear from this analysis that the amount of the state subsidy is not fairly and proportionally divided into individual municipalities. Some building officies (Tešedíkovo) have a significantly higher volume of state subsidies than other municipal offices (Jasová, Levice).

In 2013, Ftáčnik from the Union of Towns and Cities of Slovakia pointed out at least a partial solution to the lack of funds in the area of building regulations by increasing fees (Act No. 145/1995 Coll, On Administrative Fees, as amended) for the acts of bulding authorities. The proposal was rejected.

The table 3 was prepared to compare the funding of transferred competencies at the level of the building procedure between the Slovak Republic and the Czech Republic. Table 3 contains data for the Pardubice Region (CZ). The column 1 contains the names of municipalities with the building authority in the Pardubice Region. The column 2 contains the population in the PR region based on data from the Czech Statistical Office. In the column 3, there is the amount of the state subsidy allocated to a specific building authority in the Pardubice Region (the amount of the subsidy is expressed on the basis of a specific methodological procedure for calculatiion of the state subsidy for the transferred state administration in (CZ). Based on the availability of data, it was not possible to process the number of building offices activities in the Pardubice Region.

The population in the Czech Republic was 9,279,196 as of December 31, 2016 (Czech Statistical Office, 2016). The inhabitants lived in 6,257 municipalities. The total amount of state subsidy for building procedures in the Czech Republic was 37,955,259.09 EUR ${ }^{1}$ (MICZ, 2016) The amount of state subsity for building procedures from the total state subsidy in the Czech Repulic for the Pardubice Region was 5.67 per cent. The maximum volume of funds within the PR of the Region was directed to the Pardubice building office (14.83 per cent) and subsequently to the following building offices: Chrudim, Svitavy, Litomyšl etc.

The table 4 shows the following sumary data: number of municipalities, population and state subsidy for competencies in the building procedure sector in $€$ for Nitra and Pardubice Regions per year 2016.

From Table 4 we can identify the differences between the number of municipalities, the population and the amount of the state subsidy for the transferred competencies at the building procedure sector for 2016 for the Nitra and

1 The amount of the state subsidy calculated by the exchange rate NBS as of March 29, 2019; $1 €=25.786$ CZK
Pardubice regions. The Nitra Region had lower number of municipalities than the Pardubice Region but more population than the Pardubice Region. The comparative analysis showed that the Nitra Region performing the building procedure competency had by 64.82 per cent lower volume of state financial subsidy than the Pardubice Region performing the same competency.

\section{Conclusion}

The transfer of competencies from the central government to self-government has caused changes in its functioning. One of many of these competencies is the competency in the building procedure sector. This competency was transferred to municipalities from Slovak state administration bodies by the Act No. 416/2001 Coll. - Act on the Transfer of Certain Powers from State Administration to Municipalities and Higher Territorial Units, as amended.

The transfer of competencies of municipalities in the building procedure in Slovakia was carried out in two ways: at a municipal office as non-joint building office or at a joint building office.

In the Czech Republic, the powers of state administration have been transferred to municipalities by the Act No. $313 / 2002$ Coll. as amended and at the same time the powers of municipalities were divided by the Act No. 314/2002 Coll. as amended between municipalities with delegated municipal powers and municipalities with extended powers.

The aim of this paper was to investigate the consequences of the process of decentralization of public administration, in which a large number of state competencies were passed to municipalities. At the same time, the research team of the project analyzed the facts and opinions of the employees of the building offices in the Nitra Region on the staff issues of building procedure. The research team also compared the amount of state subsidy for building procedure sector in the Nitra Region and in the Pardubice Region. The research stated a financial under-dimensioning of the transferred competency, based on the interviews with employees of the building authorities and based on the compared state subsidies between the Nitra Region (Decree of the Ministry of Transport, Construction and Regional Development the Slovak Republic N. 20786/2010-SRVS/z.54145-M“) and the Pardubice Region (MICZ, 2016).

At the same time, the research came to the conclusion that the competency, which is also related to its insufficient personnel staffing, is financiallly under-compensated. For the future formation of building offices not only in the Nitra Region but also in the whole Slovakia, it would be effective to re-assess especially the state of financial subsidy for this transferred competency. 


\section{References}

BAČÍK, V. 2019. The Slovak Republic. Bratislava: UK. Online. Available on the Internet: http://www.sodbtn.sk/obce/index kraje.php

BUČEK, J. 2017. Why and When Countries Implement Local Public Administration Reforms: A Long-Term View of Reform Dynamics in Slovakia, 1990-2015. In Local government and urban governance in Europe, Urban Book Series, 2017, pp. 30-70. doi: 10.1007/978-3-319-43979-2_3

BRYSON, P. J. 2008. "State administration" vs. self-government in the Slovak and Czech Republics. In communist and postcommunist studies, vol. 41, 2008, no. 3, pp. 339-358. doi: 10.1016/j. postcomstud.2008.06.003

CZECH STATISTICAL OFFICE. 2016. Demographic and social statistics. Available on the Internet: https://vdb.czso.cz/vdbvo2/ faces/cs/index.jsf?page=statistiky

ČERNĚNKO, T. a i. 2017. Skrytý podklad v samospráve - Alternatívne možnosti sústredenia výkonu správy v samosprávach. Online. Available on the Internet: http://www.finance.gov.sk/Default. aspx?CatID $=11457$

FTÁČNIK, M. 2013. Letter to the Minister. Bratislava: The Union of Towns and Cities of Slovakia. Available on the Internet: http://www.unia-miest.sk/assets/File. ashx?id org $=600175 \&$ id dokumenty $=4359$

FUKA, J. et. al. 2016. Differences in Municipal Structure in Czech and Slovak Republic with Emphasis on Delegated Powers. Italy: $27^{\text {th }}$ International Business Information Management Association Conference. Innovation management and education excellence vision 2020: from regional development sustainability to global economic growth, vols I-VI, 2016, pp. 252-261.

HRABÁNKOVÁ, M. et al. 2010. European Union Public Administration and Development Policies and Variations in V-4 Countries. Nitra : SUA, 2010. 221 p. ISBN 978-80-552-0341-6.

HVIČŠ, O. 2017. Local administration reform and principles of public administration reform. Košice : UPJŠ. Online. Available on the Internet: https://www.law.muni.cz/sborniky/Days-of-publiclaw/files/pdf/sprava/Hvisc.pdf

KLIMOVSKÝ, D. et al. 2014. Inter-Municipal Cooperation in Lithuania and Slovakia: Does Size Structure Matter? In Lex localis-journal of local self-government, vol. 12,2014 , no. 3, pp. 643-658. doi: 10.4335/12.3.643-658(2014)

MATEJOVÁ, L. et al. 2017. Economies of Scale on the Municipal Level: Fact or Fiction in the Czech Republic? In Nispacee journal of public administration and policy, vol. 10, 2017, no. 1, pp. 39-59. doi: 10.1515/nispa-2017-0002
MARIŠOVÁ, E. et al. 2016. Administrative Law. Nitra : SUA, 2016, 204 p. ISBN 978-80-552-1567-9.

MINISTRY OF INTERIOR THE SR (MISR). 2018. Overwiev of common municipalit 25y offices in the register of Ministry Interior of SR (as at 31 September 2018). Online. Available on the Internet: https:// www.minv.sk/?prehlad SOU

MINISTRY OF THE INTERIOR OF THE CZ (MICZ). 2016. Příspěvek na výkon státní správy. Online. Available on the Internet: https://www. mvcr.cz/clanek/prispevek-na-vykon-statni-spravy-prispevek-navykon-statni-spravy.aspx

MINISTRY OF THE INTERIOR OF THE CZ (MICZ). 2016. Online. Available on the Internet: https://www.mvcr.cz/clanek/privetivyurad-obci-ii-typu-2016.aspx

THE NATIONAL AUDIT OFFICE IN THE SR (NAO). 2014. Protocol of Effectiveness and Efficiency of Performance Surveillance by tie Municipalities of the Slovak republic. Online. Available on the Internet: https://www.nku.gov.sk/ documents/10157/6058fdaa-cf0b-4d4b-b8c9-7fac28257fe0

NARBÓN PERPIÑA, I. - DeWITTE, K. 2018. Local governments efficiency: a system at icliterature review - part I. In International Transactions in Operational Research, vol. 25, 2018, no. 2, pp. 431 468. doi:10.1111/itor.12364.

NEMEC, J. 2018. Public Administration Reforms in Slovakia: Limited Outcomes (Why?). In Nispacee journal of public administration and policy, vol. 11, 2018, no. 1, pp. 115-134. doi:10.2478/ nispa-2018-0005

PARDUBICE REGION. 2011. Obce Pardubického kraje př́slušný stavební úřad. Online. Available on the Internet: https://www.pardubickykraj.cz/stavebni-rad/31508/ stavebni-urady-pardubickeho-kraje

STATISTICAL OFFICE OF THE SLOVAK REPUBLIC. 2016. Demographic and social statistics. Available on the Internet: http://datacube. statistics.sk/\#!/lang/en

ŠAFRÁNKOVÁ, J. M. - ŠIKÝR̆, M. 2019. Principles of people management in public administration. Praha : College of Regional Development and Banking Institute - AMBIS, 2019.

TOWNS AND COMMUNITIES ONLINE PORTAL. 2019. Regions Districts. Online. Available on the Internet: http://mesta.obce.cz/ 